\title{
HUMAN DIGNITY:
}

\section{A GLOBAL ETHICAL PERSPECTIVE}

Heinrich Bedford-Strohm

Centre for Public Theology

University of Bamberg

\begin{abstract}
In vastly different contexts around the world - such as South Africa and Germany - human dignity has proved itself to be an important and useful concept. Despite at times being open to political instrumentalization, Christian theology has also developed a close relationship to this concept. In this article, a theological interpretation of human dignity is developed by employing theological concepts such as the image of God, the preferential option for the poor, the commandment of love and the relational nature of being human.
\end{abstract}

Key Words: Christian Ethics, Human Dignity, Option for the Poor, Golden Rule, Relationality

\section{Introduction: Why a Reflection on Human Dignity is Necessary}

Looking at human dignity from a global ethical perspective might seem like a superfluous endeavour. It seems so obvious that the social reality of our world, shaped by a globalized economy, is in such sharp contrast to the concept of human dignity, as viewed from a Christian Humanist perspective, that no academic reflection is necessary. The fact that 25000 children die every day throughout the world, largely from malnutrition or a lack of medical care, represents such a grave violation of human dignity that we need no global ethical reflection to understand it.

Another argument against a discussion of this nature is that the term 'human dignity' is so uncontroversial that to many people it does not really mean anything anymore. Maybe some white supremacists might argue against human dignity, or maybe certain philosophical defenders of utilitarianism may argue against a Kantian approach, arguing instead for the exclusion of the idea of human dignity from a sober utilitarian cost and usefulness calculation. But those who reject a human dignity oriented approach are few, both in societal debates and indeed in academic debates. Why is it nevertheless worth the time and energy to discuss or even organize a whole conference on this theme?

The first reason is simply that this theme of human dignity is far too precious to spoil and lose in the midst of vagueness and bleariness. The possibility of appealing to human dignity and human rights (which are derived from it) has saved countless lives and opened up new possibilities for political change by de-legitimizing unjust power. The theme of human dignity has helped to make the difference between right and wrong in situations of struggle (see Naudé, 2008). ${ }^{1}$

Piet Naudé has pointed toward the struggle against apartheid as one example: "The struggle against apartheid was a search for the restoration of human dignity and the establishment of a common humanity" (Naudé, 2009). 
This brings us already to the second reason for exploring the theme of human dignity: It needs clarity in terms of its meaning. The fact that many people from very different political perspectives make reference to human dignity implies a certain sense of arbitrariness in the use of the term. However, this is not a good enough reason to avoid using the term, but rather a reason to provide a precise meaning to it. Therefore, what we need is an increased effort to explore the term in its historical development and how it is profiled in contemporary debates.

But there is a third reason to make this effort. Germany and South Africa are both increasingly pluralistic societies. In our societal debates, in constitutional law and in our public ethical infrastructure we cannot base our statements on one religious or philosophical world view alone. If we wish speak to society as a whole, we cannot simply be active and self-assured in our own religious tradition. It is also necessary that we find the terms and words that can be used as bridges between the traditions. We need ethical language that is open for what John Rawls calls 'an overlapping consensus' (Rawls, 1987, 1999). Such ethical language must be understandable to all members of society and at the same time needs vivid and passionate interpretations from the different 'strong conceptions of the good' such as the religious traditions that shape society (Huber, 2006). ${ }^{2}$ I believe the theme of human dignity is the most important theme of such an overlapping consensus. The German Constitution begins with the sentence: "The Dignity of the Human Person is inviolable" (Art. 1.1). Similarly the founding provisions in chapter 1 of the South African Constitution begin with the following sentences: "The Republic of South Africa is one, sovereign, democratic state founded on the following values: a. Human dignity, the achievement of equality and the advancement of human rights and freedoms."

The prominent place of human dignity in the moral infrastructure of our societies constitutes a clear mandate for Christian ethics insofar as Christianity is one of the formative traditions in these societies. Christian ethics must serve the common good of pluralistic societies, by exploring and specifying the meaning of human dignity, and thereby strengthening its critical impact on political debate and action.

Before you begin a hike it makes sense to find out about the dangers which you might encounter along the way, and which may prevent you from reaching your goal. Therefore, before I begin my hike towards an understanding of human dignity in a global ethical perspective, let me place a warning sign to show what I see as the biggest danger when discussing human dignity.

\section{A Warning Sign in referring to Human Dignity}

The warning sign to which I refer comes from the global experience of the theme of human dignity in the last half century. The warning sign depicts a hand with the index finger pointing outwards, with the hand and index finger crossed out. The message: No 'finger pointing' with regards to the theme of human dignity. Of course this warning sign does not prevent victims of injustice from pointing at those who cause such injustice. But it points toward the danger of the systematic exclusion of one person's action as something questioned by the theme of human dignity. This theme probably needs more than any other theme the reminder of Jesus' words on judging others: "Why do you see the speck in your neighbour's eye but do not notice the log in your own eye?" (Mt 7:3) (see Koopman \&

See Wolfgang Huber's (2006:269-320) notion of 'Begründungsoffenheit' and his concept of 'relative universality' which honours both the contextual and the universal character of human rights and human dignity (Huber, 1996:146). 
Smit, 2007). A result of ignoring the words of Jesus has led to human dignity and human rights being used for political purposes.

Let me give you two examples from recent world history. First, until the fall of the Berlin Wall and the end of the East-West confrontation, the theme of human dignity was subject to such kinds of abuse. Western governments denounced the Soviet dominated world of 'real socialism' for violating human dignity by neglecting human freedom rights. Alexander Solzhenitsyn's The Gulag Archipelago was symbolic of this criticism. The socialist countries denounced Western countries for violating human dignity by allowing large scale unemployment and poverty. Such poverty was depicted via televised pictures of homeless people looking for food in the garbage cans of American metropolises. Each super power pointed towards the violations of human dignity by the other. The theme of human dignity was not a critical measure for each super power's own policies, but as a fighting instrument in the East-West conflict.

Second, before the first Gulf War between the United States and Saddam Hussein's Iraq in 1990, Amnesty International reported on the cruelties of the Iraqi dictator against the Kurds, but these reports went by mostly unheard of by the West. At that time, Saddam Hussein was still an ally of the United States against Iran. Almost nobody was interested in his long record of attacks on human dignity. However, this situation changed almost overnight. After Saddam Hussein's attack on Kuwait and the beginning of the American war against Saddam Hussein, the telephone lines in Amnesty International's London office were constantly ringing. Everybody wanted to know about Saddam Hussein's cruelties. His poor record of human rights abuses was used to legitimize American military intervention.

These two examples show that the concept of human dignity is in danger of being instrumentalized for purposes which are contrary to its meaning. Christian ethics needs to be aware of this danger and critically examine the authenticity of its use, especially when it is introduced in political debates surrounding controversial issues.

\section{Christian Ethics and Human Dignity: A Late Romance}

Today, in Europe, particularly in France and Germany, the relationship between the churches and human rights is considered to be a close relationship. The European churches (with some exceptions in the Russian Orthodox Church) have affirmed human rights and human dignity in many recent statements.

But this relationship has to be seen as a late romance. The Protestant church - just like the Catholic one - viewed the idea of human dignity and human rights, which gradually gained ground in the Enlightenment, with deep distrust. The Jacobin terror in France, and the disempowerment of the church by the Revolution, was only one reason for this distrust. A more fundamental reason for the church's negative attitude towards the idea of human rights was to be found in the drive towards secularisation, which they saw in this idea - and not without reason. They saw it as a doctrine in which the state was founded, in the free agreement of its citizens, instead of in God. They saw it as a doctrine in which the people were regarded as having, qua natura, inalienable rights to freedom, and therefore were not subservient to God's authority and to that of the church. A doctrine of this sort seemed to the church to be an atheist ideology, which must be fought at all costs. It was not until the middle of the last century that this dismissive attitude of the church to the idea of human rights was finally overcome.

Large parts of the Protestant church in Germany had an anti-Enlightenment tendency in the $20^{\text {th }}$ century. Such anti-Enlightenment sentiment was present in the introductory speech 
of Hans Asmussen at the synod of Barmen in 1934, where the Barmen Theological Declaration became the founding document of the confessing church. In his speech, Asmussen identified the reasons for the National Socialist attack on the church to be due the 'errors' that have burdened the church 'in the last 200 years.' It is clear that he was speaking of the Enlightenment - a quite adventurous thesis which did, however, find sympathetic listeners (Bedford-Strohm, 2008).

On the Protestant side, after the war, the ecumenical movement provided an important stimulus for overcoming the attitude, which called into question the idea of human dignity and human rights. An important step here was the Conference of World Churches in Amsterdam in 1948, where the old democracies of England and the USA helped influence German Protestantism, after having been more or less humbled by the errors of the Third Reich, to become more open to human dignity and human rights. Later, the Evangelischen Kirche in Deutschland (EKD) Denkschriften made it clear that the idea of human dignity had become an integral component of the socio-ethical ideology of German Protestantism, thus aligning themselves with the wider ecumenical community of churches. With good reasons, Dirkie Smit has stated that "contemporary ecumenical theology (after an initial hesitation)... strongly supports theoretical paradigms in which human rights, as the concrete embodiment of human dignity, are central" (Smit, 2007:352). This learning process was strongly supported by an intense reading of the Bible.

\section{A Biblical Theological Interpretation of Human Dignity}

There has been a long history of struggle for human dignity and human rights and in many cases this struggle has been against the churches and institutionalized Christianity. However, biblical sources and reference points regarding human dignity are equally supportive of this concept.

\section{Human Being Created in God's Image}

The affirmation that human beings are created in the image of God (Gen 1:27) is a qualification of human dignity that cannot be underestimated. Recent biblical scholarship has not only explored the exact meaning of this passage (Gross, 2001), but has also shown its relevance for an ethical assessment of human dignity. Such dignity is given to human beings by their close link to God and thereby affirming a relationship between God and human beings that cannot be destroyed by human misbehaviour, not even by murder, as one of the most despicable forms of moral misbehaviour. When Cain murdered his brother Abel, he is not subject to revenge - as one would expect - but instead God protects the murderer: "The Lord put a mark on Cain, so that no one who came upon him would kill him" (Gen 4:15). This story follows immediately after the Creation story and the story of the Fall and it can be understood to support the idea of the human being as created in God's image under the conditions of sin. Even the murderer is protected against revenge, because he remains God's creature created in God's image.

In Psalm 8:5 we find a very similar qualification of human beings: "Yet you have made them a little lower than God and crowned them with your glory and honour." Ute Neumann-Gorsolke, in her exegetical study of this text, shows that the god-kingly qualifications of dignity indicate the investiture and elevation of the human being to the office of a king. She also makes it clear that these god-kingly qualifications of dignity cannot be understood as special abilities, but that they stem from God's gracious love (Neumann-Gorsolke, 2001). Therefore, the dignity of the human being is not based on 
achievement, but on God's grace. Those rights that are connected to the dignity of the human person are also to be guaranteed to the socially marginalized, the sick, or those who are dependant in any way. Thus, says Neumann-Gorsolke, the biblical affirmation of the kingly dignity of the human being has a clear egalitarian meaning (Neumann-Gorsolke, 2001).

Even though passages on human beings as created in God's image are to be found in only a few places in the Bible, the idea which is behind this theme and which shapes the idea of human dignity is prominent not only in the Old Testament, but also in the New Testament. For example, Paul's theology does not explicitly discuss the imago Dei theme, but as a new study by Marlies Gielen has shown, its fundamental idea, as interpreted through Christology, is at the basis of Paul's theology. She interprets Romans 3:21-26 with its emphasis on righteousness not by good works, but by faith in Jesus Christ, as a witness for God's restoration of the imago Dei in human beings (Gielen, 2001), thus leading human beings to be the 'image of Christ' (Gielen, 2001:140). She sums her thoughts up by the following:

To speak of the dignity of the human being is alien to Paul. Its meaning, however, is deeply rooted in his anthropology. This dignity, to be sure, is intelligible in Paul's thought not from human action but from God's action toward humanity through Christ. This action shows that human beings are, despite the power that death has over them, called to justice and righteousness and to life through the power of God. Independently of whether human beings open themselves up to this calling or remain closed, it is the root of their inviolable dignity as a person (Gielen, 2001:147). ${ }^{3}$

The idea of human dignity as being something that is attributed, and which cannot be lost or denied by others, is an idea with high relevance for contemporary issues. It can be seen as one of the greatest cultural achievements of the Judaeo-Christian tradition. By exploring and explaining human knowledge regarding this idea of imago Dei, Michael Welker has stated that theology carries this perspective into non-religious contexts. He said it does a great service to humane political ideas and a humane legal culture, as well as providing a communicative moral infrastructure oriented towards universal values (Welker, 2001).

Scholarship on imago Dei and human dignity has so far neglected the close connection between these themes, including another theme central to various biblical traditions: the preferential option for the poor (Boff \& Pixley, 1987; Bedford-Strohm, 1993).

\section{Preferential Option for the Poor}

We can only understand why the option for the poor has been given such a prominent place in the Bible when we see it as affirming that human beings are created in God's image. The special sensitivity towards the poor and marginalized is a response to the scandal when human beings are not treated with the dignity they deserve. This dignity flows from the fact that people are created in the image of God. Preference for the poor is necessary and appropriate as long as there are people whose 'kingly dignity' is gravely denied. Preference for the poor would no longer be necessary if all human beings could live a life without material, physical and spiritual threats being brought upon them by their fellow human beings.

This is my own translation. 
I will not repeat the impressive biblical evidence for the preferential option for the poor, a fundamental source of ethical ideas guided by biblical tradition. But let me give at least a few reminders. The unique experience of Israel's story with God originates from the protest against the violation of human dignity in the work place. I refer to Moses' encounter with God in the burning bush, a direct consequence of his flight from Egypt into the land of Midian. Why did he have to flee? The story is told in Exodus 2:11f: "One day, after Moses had grown up, he went out to his people and saw their forced labour. He saw an Egyptian beating a Hebrew, one of his kinsfolk. He looked this way and that, and seeing no one he killed the Egyptian and hid him in the sand." The next day he hears people talk about what he did and decides to flee.

Moses' violent reaction to the injustice that he witnessed can certainly not be condoned. However, the fact that it is his moral outrage, which leads him to commit this deed, is no coincidence. It is at the core of what drives the relationship between God and Israel and it is a fundamental characteristic of the Judaeo-Christian tradition. God's response to the injustices which Israel has to endure is to promise them liberation. And God chooses this man, Moses, who is driven by a passion for justice to be the means of God's liberation from oppression. From the burning bush God says to Moses:

I have observed the misery of my people who are in Egypt; I have heard their cry on account of their taskmasters. Indeed, I know their sufferings, and I have come down to deliver them from the Egyptians, and to bring them up out of that land to a good and broad land, a land flowing with milk and honey... The cry of the Israelites has now come to me; I have also seen how the Egyptians oppress them. So come, I will send you to Pharaoh to bring my people, the Israelites, out of Egypt (Ex 3:8-10).

This is no biblical sideline! This is no detail that can be ignored! It is the most decisive moment in the whole history of God and God's people. This God is not only a God of the poor in words. This God acts in history. This God changes history. This God leads the oppressed out of their situation of oppression into a life of dignity and mutual respect.

Therefore, it is not surprising that the law, which is given to Israel, is profoundly rooted in this experience. It is a fascinating trait of the moral tradition in the Bible that it is not simply a law imposed on the people as something to obey, but rather a set of rules that can guide God's people into a life of fulfilment and which are presented as an authentic dimension of their own story. The biblical laws, which mirror God's option for the poor, are introduced by a reminder of Israel's own story of liberation: "For the LORD your God is God of gods and Lord of lords, the great God, mighty and awesome, who is not partial and takes no bribe, who executes justice for the orphan and the widow, and who loves the strangers, providing them food and clothing. You shall also love the stranger, for you were strangers in the land of Egypt" (Dt 10:17-19). This rationale expresses the origin of love among humans in their human-divine relationship. The commandment does not say simply: "You ought to love the poor or the foreigner!" Rather, the commandment is promoted in two ways. First, the commandment is emphasized as comprehensible and accessible due to Israel's own experience: "You know how it feels to be poor and marginalized. Therefore, treat the poor and marginalized just like you would want to be treated if you were in the same situation!" Second, God refers to Himself when explaining the reasoning behind the commandment: "I am the Lord your God. I adopt the cause of the poor just like I adopted your cause. I am your God, I love the poor. Therefore, be in solidarity with the poor just like me!" What we see here is a sense of mutuality and reciprocity rather than sacrifice. The idea is not an appeal to the rich and powerful to empty themselves and reach out to the 
poor, but rather to a sense of mutual respect. It is not simply a logic of donation, but a logic of dignity.

\section{The Commandment of Love and the Golden Rule as Affirmations of Human Dignity}

This logic of dignity becomes even more apparent when we contemplate the close connection between the commandment of love and the so called 'Golden Rule': "So in everything, do to others what you would have them do to you, for this sums up the Law and the Prophets." (Mt 7:12). The Golden Rule does not demand sacrifice, but the simple acknowledgment of mutual respect. The only other place where we find this phrase about the Law and the Prophets is the double commandment of love: "You shall love the Lord your God with all your heart, and with all your soul, and with all your mind.' This is the greatest and first commandment. And a second is like it: 'You shall love your neighbour as yourself.' On these two commandments hang all the law and the prophets" (Mt 22:37-40).

This close connection between the love commandment and the Golden Rule is quite significant for the interpretation of the love commandment. Apparently, the love commandment is not a commandment of self-sacrifice, but a commandment affirming reciprocity, based on human dignity. Each person has an equal entitlement to be treated with dignity.

To be sure - talking about rights and entitlements, rather than simply love, does not imply a reduction in Christian agapé regarding the necessity to struggle and fight for rights. However, the logic of rights must always be imbedded in the logic of relationship.

\section{Human Dignity means being in Relationship}

To understand the theological reason underlying this affirmation we must point toward the central significance of Christology for our understanding of human dignity. The relational character of what it means to be human is probably the 'cantus firmus', the one melody, of Christian anthropology.

The $20^{\text {th }}$ century Swiss theologian Karl Barth has, in his multi-volume church dogmatics, strongly emphasized this relational characteristic by centring it on Christology. What it means to be a human being can only be understood if we interpret it from its primary 'text' which is the humanity of Jesus. Therefore, "Whoever does not know and take into account from the very first place and from the very first view and word that the human being has a fellow human being does not see him or her at all" (Barth, 1948:270). It is, of course, crucial for theological anthropology to understand how specific this Christological foundation is. It does not suffice to simply speak of some general humanity with some general relationality. Such humanity and such relationality need to be qualified. Jesus is the vulnerable human being, the tortured human being, the powerlessly abused human being. Therefore, relationality from a theological perspective is relationality 'from below'.

The importance of this specification should not be underestimated. Both the justification of apartheid by certain theological ideas from Abraham Kuyper (see Naudé, 2008) and the support of National Socialism by neo-Lutheran creation order theology, show how distorted anthropology can become if relationality is not viewed from below. Therefore, the New Testament displays quite radical language for the close relationship between faith in Jesus Christ and a relationship to the poor. It sees the integration of the poor and marginalized as a fundamental dimension of the insoluble interconnection between love of God and love of neighbour. In the famous vision of the Last Judgment in Matthew 25, Christ presents our relationship to the hungry, the thirsty, the stranger, the naked, the sick and the prisoner as 
the main criterion for a relationship with himself, as he says: "I was hungry and you gave me food..." (Mt 25:35). Obviously, ethical questions cannot be separated from questions of faith. "Truly I tell you, just as you did not do it to one of the least of these, you did not do it to me" (Mt 25:45).

We can conclude that Christian faith leads to a radical commitment to realizing human dignity in the very concrete circumstances of daily life, as much as in relation to the political structures that are formative for such daily life. Human dignity, in light of the biblical tradition, must be interpreted through the preferential option for the poor. This biblically based theological perspective is confirmed as relevant for all people of good will when we look at the philosophical sources of human dignity.

\section{Human Dignity: A Philosophical Perspective}

Human dignity as a term and as an idea found a profound promoter in the Enlightenment tradition in Europe and the United States in the $18^{\text {th }}$ and $19^{\text {th }}$ centuries. In Germany, the most impressive example was the philosopher Immanuel Kant. When we look at the challenges of globalization and its effects on human beings and their dignity, Kant's explanation of the term 'human dignity' seems almost prophetic.

His fundamental defence of human dignity is directed against the commodification of human beings in a world dominated by economic considerations. When speaking of human dignity, Kant emphasizes that human beings are never to be treated only as means to certain ends, but always as ends in themselves. What the intrinsic worth and beauty of every human person means can be better understood if we look at Kant's explanation of the term 'dignity'. He explains the meaning of this term by distinguishing it from an economic value: "What has a price, can be replaced by something else that is equivalent. What exists above all price, what does not allow any equivalent, has dignity" (Kant, 1785). ${ }^{4}$ Kant uses the economic paradigm here to clarify the difference between treating life with dignity and treating life as a commodity. This is actually the greatest danger which we face today, because our lives are being shaped more and more by the economic paradigm of commodity. Hence, we are in danger of allowing this paradigm to enter every aspect of life - even at the very beginning of life in the case of human reproduction.

\section{Consequences for a Global Ethic}

The consequences of such an account of human dignity for a global ethic are obvious. I will only mention a few. If human dignity does not need to be earned, but is attributed unconditionally, this must have economic consequences. The clear goal for the global community must be an unconditional basic income for every human being on this earth.

Beyond socio-cultural existence, the inherent human dignity of each human being also implies certain rules for the treatment of those who are able to earn their living by their own labour. Minimal social standards for the labour force, such as those established by the International Labour Organization, must be binding for all companies worldwide. This also implies the overcoming of child labour.

Every human being must have safe access to basic health care. Since this is, in many cases, a matter of life and death, it is one of the most urgent implications of a world viewed from a human dignity perspective.

"Was einen Preis hat, an dessen Stelle kann... etwas anderes als Äquivalent gesetzt werden; was dagegen über allen Preis erhaben ist, mithin kein Äquivalent verstattet, das hat eine Würde" (Kant, 1785:434). 
Our exploration of the theme of human dignity from a theological perspective has shown that demands like these are not appeals to human pity. They are consequences of the right of every human being to participate (equally) in economic and societal processes worldwide. The consequences for the democratization of international political and economic institutions like the World Bank, the International Monetary Fund and the World Trade Organisation, must move into the centre of global politics. The churches are called to be advocates of such democratization.

What Nico Koopman and Dirkie Smit have stated regarding the community of South African ecumenical churches applies to churches worldwide. They stated that there is a need to show "very strong commitment to support human dignity as guiding principle for life together, including our economic life, and accordingly the increased implementation of social and economic rights..." (Koopman \& Smit, 2007:278).

I conclude by emphasizing why the theme of human dignity is so important for a global ethic. The fact that there is such wide consensus on the fundamental importance of this theme is not a vice, but a virtue. It is a common ground to which we can appeal when we struggle against injustice. Wherever people are used purely as a means to an end and not as ends in themselves, we can criticize it and struggle against it in the name of human dignity. And precisely because it is so widely shared, we will have strong support for this idea. Its force is so strong, because the consensus to which it can appeal is global.

To reshape the world in a way that every human being can live in dignity is maybe one of the most difficult tasks we face. However, it is also the most worthy and promising task we can imagine. We have seen the collapse of our global financial system, and with this, we have also seen the collapse of neo-liberal ideologies. There are signs of a growing understanding of the need for the right balance between the role of the market and the role of government to make sure that the weakest members of society also profit from its wealth (EKD, 2009). ${ }^{5}$ We have witnessed the election of a new American president who has chosen human dignity as one of the themes of his tenure. The times have hardly ever been more promising for the dawn of a new global movement for the actualisation of human dignity. Christians should be the first to speak out about this wonderful concept.

5 See reasons for the need to re-orientate the economic system - the public memorandum on the economic crisis by the German Protestant churches "Wie ein Riss in einer hohen Mauer. Wort des Rates der Evangelischen Kirche in Deutschland zur globalen Finanzmarkt- und Wirtschaftskrise" (EKD, 2009). 


\section{BIBLIOGRAPHY}

Barth, K 1948. Die kirchliche Dogmatik, Vol III/2: Die Lehre von der Schöpfung. Zürich: Evangelischer Verlag AG Zollikon.

Bedford-Strohm, H 2008. Öffentliche Theologie in der Zivilgesellschaft. In I Gabriel (hg.), Politik und Theologie in Europa. Perspektiven ökumenischer Sozialethik, (pp. 340366). Mainz: Matthias-Grunewald-Verlag.

Bedford-Strohm, H 1993. Vorrang für die Armen: Auf dem Weg zu Einer Theologischen Theorie der Gerechtigkeit. Gütersloh: Chr. Kaiser Gütersloher Verlagshaus.

Boff, C \& Pixley, J 1987. Die Option für die Armen. Düsseldorf: Patmos.

EKD 2009. Wie ein Riss in einer hohen Mauer. Wort des Rates der Evangelischen Kirche in Deutschland zur globalen Finanzmarkt- und Wirtschaftskrise (EKD-Texte 100). Hannover: EKD.

Gielen, M 2001. Grundzüge der paulinischen Anthropologie im Licht des eschatologischen Heilsgeschehens in Jesus Christus. In Menschenwürde. Jahrbuch für Biblische Theologie, 15, 117-147.

Groß, W 2001. Statue oder Ebenbild Gottes? Aufgabe und Würde des Menschen nach dem hebräischen und griechischen Wortlaut. Menschenwürde. Jahrbuch für Biblische Theologie, 15, 11-38.

Huber, W 2006. Gerechtigkeit und Recht. Grundlinien christlicher Rechtsethik ( ${ }^{\text {rd }}$ ed.). Gütersloh: Chr. Kaiser/Gütersloher Verlagshaus.

Huber, W 1996. Violence. The unrelenting assault on human dignity. Minneapolis: Fortress Press.

Kant, I 1785. Grundlegung zur Metaphysik der Sitten, 1785, Akad.-Ausgabe IV, 434.

Koopman, N \& Smit, D 2007. Public witness in the economic sphere? On human dignity as a theological perspective. In L Hansen (ed.), Christian in public. Aims, methodologies and issues in Public Theology (pp. 269-280). Stellenbosch: African Sun Media.

Naudé, P 2008. It is your duty to be human. Anthropological questions in a post-liberation South Africa. Criterion, 46(2), 6-21.

Neumann-Gorsolke, U 2001. "Mit Ehre und Hoheit hast du ihn gekrönt" (Ps 8,6b). Alttestamentliche Aspekte zum Thema Menschenwürde. Menschenwürde. Jahrbuch für Biblische Theologie, 15, 39-65.

Rawls, J 1999. Collected papers (S Freeman, (ed.)). Cambridge, MA: Harvard University Press.

Rawls, J 1987. The idea of an overlapping consensus. Oxford Journal of Legal Studies, $7(1), 1-25$.

Smit, D 2007. Essays in Public Theology. Collected Essays 1. (E Conradie, (ed.)). Stellenbosch: SUNPReSS.

Welker, M 2001. Person, Menschenwürde und Gottebenbildlichkeit. Menschenwürde. Jahrbuch für Biblische Theologie, 15, (247-262). 